\title{
Eastern Europe Consumer Attitude Towards Made in China Products and China as a Country Brand: a Romanian Perspective
}

\author{
Yan Hui; Elena Marin \\ School of Management, Shanghai University, 99 Shangda Rd., Shanghai, China
}

\begin{abstract}
During the past few years China's economical growth was studied throughout as being one of the biggest manufacturing country in the world. Most of the products label containMade in China printed on it, thusmaking other markets wonder: what are the consumer perception about buying and using those products?This paper aims to take a closer look and analyse, if the Romanian buyers consider these products as a challenge for the goods from other countries. Another aspect, the paper intends to research is if China identifies with the products it manufactures. The research is based on the consumer behaviour as well it measured the differences between age, the amount of money spent by the consumers and the perception of the Chinese goods and China as a country.To collect the necessary data, was designed a questionnaire that was handed to the Romanian consumers, mostly from the West-North part of Romania.
\end{abstract}

Keywords:Romania, made in, consumer perception, country image, Eastern Europe

\section{Introduction}

In 2014 China became the world's biggest economy in purchasing power-parity (Economist, 2014). Despites all the economical achievements, is still considered to be a country in the developing stage. Previous studies show that products that are coming from developed countries are perceived of a higher quality(Josiassen \& Harzing, 2008) and on the opposite pole are in developing stage countries(Hulland, Todino, \& Lecraw, 1996). Analysing the global market, China is still seen as an image of low-cost producer, despite the high growth of the economy (Chinen \& Sun, 2011). Although it cannot be denied that the most known label is Made in China. Although after the Chinese boom of products, the Western countries are repent due to quality awareness (Wagner, 2008). Made in label is usually considered to be the country of origin (COO), and it is often used for the evaluation of a product (Wilky \& Nes, 1982). Positive image of country of origin can be used as a marketing tool and as an increase on the value of a product (Vrontis, Thrassou, \& Vignali, 2006)

The core question is if the country can be differentiated through the products it manufactures. It is important to analyse the opportunities and the threats Made in China goods can have on a global scale. Since the age and the amount of the money spent by the consumers is a major index in the purchasing decisions, we have taken these factors in consideration for the paper. The research topic has two objectives: practical and academic. On the one hand, the academic point of view, there were no other studies that measured the Romanian consumer attitude towards the products Made in China. On the other hand, it can be practical use for Chinese exporters and China as a government. Knowing and acknowledge the current position in buyer's mind not only affect the choices they made, but also the association of the products and the manufacturing country, can increase or decrease the investments and the tourism from Romania.

\section{Objectives and Hypothesis}

\section{Methodology}

The main objective of this paper is to investigate Romanian's consumer perception about the products Made in China. The secondary objective is to see if the positioning of the products can be identified with the country image, means China country brand can be identified with products it manufactures.Drawing from the insights of several research papers(Gtai, 2015)(Baladi, 2012), it is presented a simple conceptual model formed to bring to discussion the binding of the label, country brand and the factors that influence it. Out of all the $\mathrm{COO}$ or Made in label research model, it was chosen to work with Charles Osgood's theory, modified later by W.A. Mindak(Nagashima A. , 1977). This method will be partially used, it provides the opportunity not only to measure the influence of the label on the customer, but as well to analyse the perception of the products. The paper is focused on knowing how China can use its current positioning to change or to strengthen it. In order to make any statement about the marketing tool of the country brand, it was used a part of the Anholt-GFK research methodology(Anholt S. , 2008). Taking in consideration the complexity of the method, the main focus was the culture of the people, the cliché and stereotypes formed, that can be formed based on the knowledge and the experience gained(Nagashima, 1970). The effects of the country of origin on the consumer buying decision has been widely studied(Keith, 2003). Thisresearch will start from the question: What problems can face the country brand being positioned based on low price product?(Williams, 2010). Taking this in consideration was 
formed $\mathrm{H} 1$ and $\mathrm{H} 2$. The first hypothesis $\mathrm{H} 1$ The age influence the perception of the Chinese manufactured products. The figure bellow (Figure 1) shows the factors that influence the country brand and the label Made in China. The service and engineer factor refers to distribution worldwide of the products, the level of innovation; technical advance and the environmental impact. Romania is an EU country and it is very important for its consumers that the products they buy and use are ecological and will not lead to pollution. According to the results it will be possible to make comments and suggestions on how to implement a new strategy to improve customer perception.

From the point of view of some researchers(Kahneman, Tversky, \& Slovic, 1981)(McEwen, 2005) the country of origin influences directly the positioning of its products. Can identify itself with the manufactured products? The second working hypothesis is $\mathrm{H2}$ : China as a country does not identify itself with the manufactured products. According toAnholt-GFK(Anholt S. , 2007), the economical factor has a big influence on the image of the country. Country of Origin effect, which consist in association by consumers of the products with the reputation of the country(Anholt S. , 2003).Nowadays country brand is identified with the corporative product branding. Country branding refers to the way a country is attracting consumers/tourists/entrepreneurs, by offering experience and how it is market itself (Kotler \& Armstrong, 2004). Thus, in the absence of this mechanism of applying the positive impact on the country, it is impossible to exploit their full potential and develop competitive advantage around the countries in the world (Moilanen, 2008).

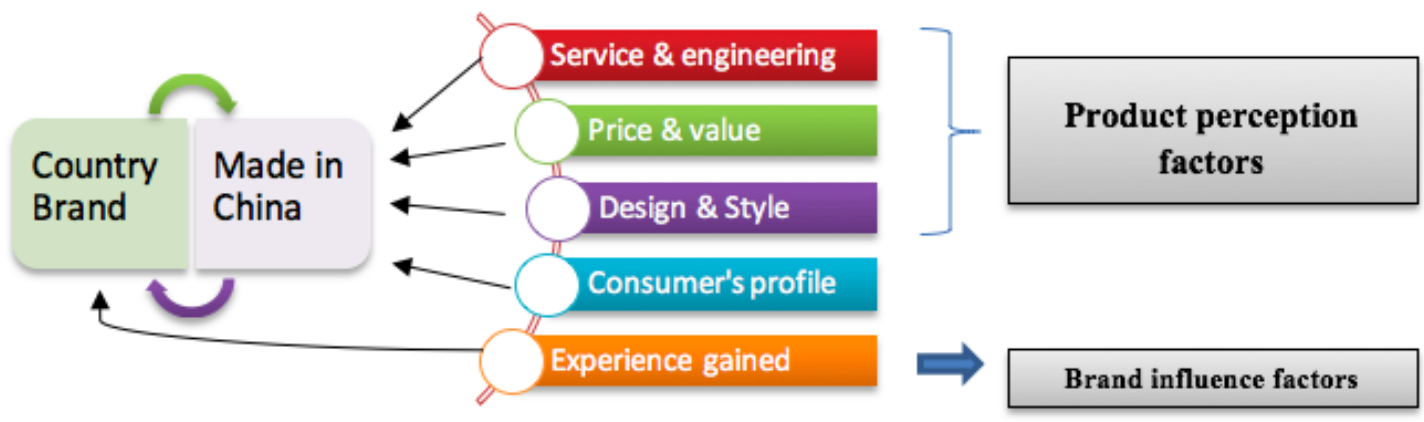

Figure 1Variables influence on country brand and label

The differences of age and amount of money a customer is willing to pay, is also a factor that matters in terms of choosing the products. Price and value is all about the positioning of the label and the brand, expensive/inexpensive; luxury/ not luxury and the amount of time and money worth spend on the products, (FutureBrand, 2014-15). Consumer's profile indicates the age and income of the questioned people, as these factors have the power to differentiate the population. The higher the income the more people are spending on luxury products, but in the analysis we will know if it is also about the cheap ones(Aaker, 1991). The age dominance is showing the generation gaps and who is more open to buy products from China, older or younger generation. From this observation have been developed the hypothesis H3: The younger generation is buying more Made in China products than the one elder. In the Osgood theory, the factor of price and value has a direct correlation with the population profile. As well when it comes to younger generation, they are open to more new and innovative products. When it comes to the age differences, one variable that will help to understand if the customer is open to new things is analysing based on the design factor(Sexton, 2008). The design and style is the last variable in the method used to determine if the range, size and models of the products on the label Made in China is a strength or a weakness. It will let observe if the country has a focus point or not (referring to Made in Japan whose country main focus is innovation and robotics). The hypothesis H4: The younger consumers have a better knowledge and perception of Chinese manufactured products. The hypothesis was build based on the variable of Anholt model. Experience gained is all about the influence on the country brand. Most of the people have different ways of forming an impression: from own buying experience, influenced by internet, family, word of mouth etc. in this way it will be possible to determinate if it is about the culture, the stereotypes, clichés or it is about the knowledge the person received through years(Kotler \& Armstrong, 2004).Target population \& Limitation

Target population consists of people with age between 18-55, that have heard about China and have bought products Made in China. This agewas selected because in Romania you are an adult at 18 years and start to gain knowledge and be independent and limited with 55 yearsold, because this is usually when people are still going shopping and can try something new. One of limitation in this context was that the survey was mostly in the North-West part of Romania, also known as Transylvania.The method used was an empirical analysis, 
because of the short time and limited costs. The survey was held online, taking in consideration the distance and impossibility of the researcher to make an investigation "on field". This is another limitation of the research, when you cannot observe the actual behaviour, or the time the consumers are spending between thinking and answering the questionnaire. Also, one of the limits of the paper is mostly focusing on one of the Eastern Europe countries, although Romania was chosen because it is situated in Eastern Europe, and entered in 2007 the European Union, that means it has all the standards to be the representative country for the research.

\section{Data collection}

The data can be collected in a number of ways: observation, questionnaire etc. The latter is the most used survey data collection technique. The advantage of this type of collection is that the respondents are answering all the same questions. To gather the information needed for this study a questionnaire method was used. It was introduced on isondaje.ro, and after spread online to the population aged 18-55 on websites like facebook.com, gmail.com, skype.com and yahoo.com. The amount of population that took part for this questionnaire was 262 respondents. The questionnaire was first elaborated in English, after translated in Romanian, and retranslated in English by a graduate student from "Babes-Bolyai" University, majoring in English-Romanian Language. The questions were mostly formed from fix answers, 2 from 10 were open questions, so that the people could answer about their own vision of China as a country and Made in China products, not to be influenced by the researcher opinion. Also it consists of two identification question, that helped to divide the analysis and compare between the population. Taking this in consideration we have a quantitative research with few qualitative points. The start point of the questionnaire consists of two qualitative questions, so that it can be seen the attitude towards China without being influenced and with its own knowledge. Afterwards few more are added so that the consumers may fill up their own ideas. Thus, the questionnaire is the most known and efficient way of collecting data, that is an advantage for this survey. The limitation that consist in gathering the data online (the collecting wasn't supervised directly) so the questioned population could inform themselves of the questions that were researched. Also it is hard to form a perfect questionnaire, the one used for the research was particularly formed for this study and has its best interest.

\section{Analysis}

For analysing the data, and supporting the hypothesis, first of all it is needed to verify the perception about the country. It was possible with the help of spontaneous answer to the question: (What words are coming to mind when they hear about China?). Analysing the results top three answers were regarding the actual facts about the country like: the biggest population and a big country (110 times mentioned); also communism and growing economy (96 times).also the symbols of the country and the places like Shanghai, Great Wall, Beijing, Pandas and Dragons (93 times mentioned). Other types of association for the Romanians are: good food (84 times); rich history (83 times); pollution (56 times); low prices (54 times); the impression about the population like hard-working, peaceful and not tall people (53 times mentioned); the lowest points had technology and innovation (30 times); bad quality (33 times); poverty (18 times).

Table 1 Correlation between the age and the statements about the Made in China products

\begin{tabular}{|c|c|c|c|c|c|c|c|c|}
\hline \multicolumn{9}{|c|}{ Correlations } \\
\hline & & & Age & $\begin{array}{c}\text { Good } \\
\text { quality }\end{array}$ & Low Price & $\begin{array}{l}\text { Easy to } \\
\text { find }\end{array}$ & $\begin{array}{l}\text { Environmental } \\
\text { friendly }\end{array}$ & A marketing tool \\
\hline \multirow[t]{3}{*}{$\begin{array}{l}\text { Spearman } \\
\text { 's rho }\end{array}$} & \multirow[t]{3}{*}{ Age } & $\begin{array}{l}\text { Correlation } \\
\text { Coefficient }\end{array}$ & 1.000 & $.325^{*}$ & $.234^{* *}$ & $.212^{* *}$ & $.288^{* *}$ & -.120 \\
\hline & & $\begin{array}{l}\text { Sig. (2- } \\
\text { tailed) }\end{array}$ & & .000 & .000 & .001 & .000 & .053 \\
\hline & & $\mathrm{N}$ & 262 & 262 & 262 & 262 & 262 & 262 \\
\hline
\end{tabular}

For the first hypothesis, it was used the spontaneous answers of the respondents, so that they would be sincere in describing the label Made in China. After counting the first 3 things that come into Romanian's consumer mind, the label had a lot of negative reviews. At least one negative association was present in the questionnaire. The top three things are: Cheap (141 remarks); low-quality (119 times) and mass-production (115 times). As surprising as it can be, right after the top three are coming more positive remarks like: a big variation of products ( 80 times); improved quality (62 times mentioned); creativity and performances (49 times). The other things mentioned were: creating monopoly (53 times); counterfeit (59 times); unhealthy (31 times) as well as violation of labour law (31 times). For being sure in the results, another question had to prove that the customers were honest.The Spearman's rho test (table 1), shows a significant correlation between the age of the 
respondents and the perception of the manufactured in China products (Sig.<0.05). Made in China products have a negative perception among the Romanian consumers, so the hypothesis is supported (H1).

Some of the countries can be identified with the products it's manufacture. The next hypothesis is to see if the products have any influence on the country of origin (China). The consumers were asked what do they think "made in" label express, to understand how much they identify the products with the country. From theanalysis resultthat $56 \%$ of the people analysed consider the label as being both a Chinese brand as well as manufactured in China; 33\% associate it solely with the products from China; 11\% consider it the Chinese brand.The conclusion either China is identifying itself with the products, was made from expressing the attitude toward the statement "The image of China can be defined with the products it manufactures" (Graph 1). The younger respondents were divided, but the older were totally positive about the statement. The hypothesis is supported (H2).

Taking in consideration the first analysis of the label it mostly has a negative impact on the image of China, because earlier resultsshowed that products have rather a negative, then a positive association. The younger generation is well known for buying a lot of things, because the times changed. H3 is based on the amount of the products purchased from China. The lower income is the meaning of more buying cheaper products, as defined before most of the population perceives products manufactured in China as low price. Graph 2 is showing that lower the income the more products bought from China, also the younger people have a lower income. The hypothesis $\mathrm{H} 3$ is supported by the graph 3, where most of the products are bought mostly by young people.

Table2Correlation between the Perception created by friends and family and age

\begin{tabular}{|l|l|l|l|l|l|l|}
\hline \multicolumn{2}{|l|}{ ANOVA } & $\begin{array}{l}\text { Sum of } \\
\text { Squares }\end{array}$ & df & Mean Square & F & Sig. \\
\hline $\begin{array}{l}\text { Perception created } \\
\text { by: Friends and } \\
\text { relatives }\end{array}$ & $\begin{array}{l}\text { Between } \\
\text { Groups }\end{array}$ & 18.649 & 2 & 9.325 & 7.485 & .001 \\
\cline { 2 - 8 } & $\begin{array}{l}\text { Within } \\
\text { Groups }\end{array}$ & 322.664 & 259 & 1.246 & & \\
\cline { 2 - 8 } & Total & 341.313 & 261 & & & \\
\hline
\end{tabular}

Anova test was used to analyse if the age has any correlation with the opinion created by the consumers, or the influence others had on them. It was showing a significant correlation only for the perception created by friends and relatives and the age of the population: Sig. $=0.03<0.05$ (table 2). An easier look will be from the Graph bellow, because the elder population are more based on what other say, they can be considered more influenced by family. $\mathrm{H} 4$ is supported base on the correlation of age and experience in buying Chinese products. As well fromH3 it can be seen that knowledge and the amount of bought products are higher in case of young generation, it means the significance of the own purchasing experience is high and the perception is better.

\section{Conclusion}

Themajor thrust of the research is to analyse if there exist a relation between the label: Made in China and the image of the country and if the perception of the people from Eastern Europe, Romania. The influence of country of origin in developed markets were examined thoroughly (Ozretic-Dosen, Skare, \& Krupka, 2007), although no information about the Romanian consumers attitude towards an emerging market such as China was found. This paper extends this research as to see the impact the country name has on the overall purchasing tendency.The findings showed interesting results, when it is coming to associate the label with the country it can be observed that it is very tight correlated. The opinion about China is a mix between knowledge about the country and the manufactured products. Most of them are interested to visit the country, or taste the Chinese food in their own country, instead of choosing the Chinese goods. The counterfeit brands are very wide spread between the foreign markets. Now, these two factors, the admiration for the country, and the doubts about the product quality, may explain the dichotomy of the preferences to keep buying the EU products. Having the results and knowing the relation between the country of origin and the country brand, it is very useful for the future changes of China. What kind of association do the Chinese people want their country to have (Shimp \& Sharma, 1987). A grand opening of a new invention, a new model of doing business, as well as a good marketing program, can make China from a country that copies everything, to a country that is copied. Compare to the JWTInteligence research where the made in China products tent to lay behind the other countries, Romanian consumers believe that the products can be trusted and positioned as middle class.

Even if the perception of bad quality and low price is still very strong in Europe, the paper draws a distinction between the Romanian younger generation that tends to believe that the country's products are evolving in a better way and the older generation which are still traditional in the first impression of long ago.The research highline the way Europeans think about the products, and the associations they make are not 
the most positive and the reasons they consider not to buy is also one of the causalities. One of the most interesting facts was that the consumers understand that not all the Made in China products are low quality, but they believe that the ones that can be find in their country are the one from mass-production, that means it's harmful and tend to lead to mistrust. This is especially seen from the analysis that the younger generation described the Chinese goods as being innovative, different and having an improved quality.

Finally, the research can contribute to the existing made in label literature, by providing further information on the Romanian consumer behaviour towards an emerging country. The practical usage of the study can be seen as how to understand the Romanian customers. The most important thing is the safety of the products, as well as the products have to be environmental friendly. Ecological problem is a big issue nowadays in Europe. If China wants to be seen in a brighter light for foreigners, it has to start by changing the regulation for export. Making a more rigid standardization of the products, and control the products before exporting them will increase the cost of the country, but mostly will increase the image of China. It will also decrease the scandals that were so many along the time.

\section{Appendix}

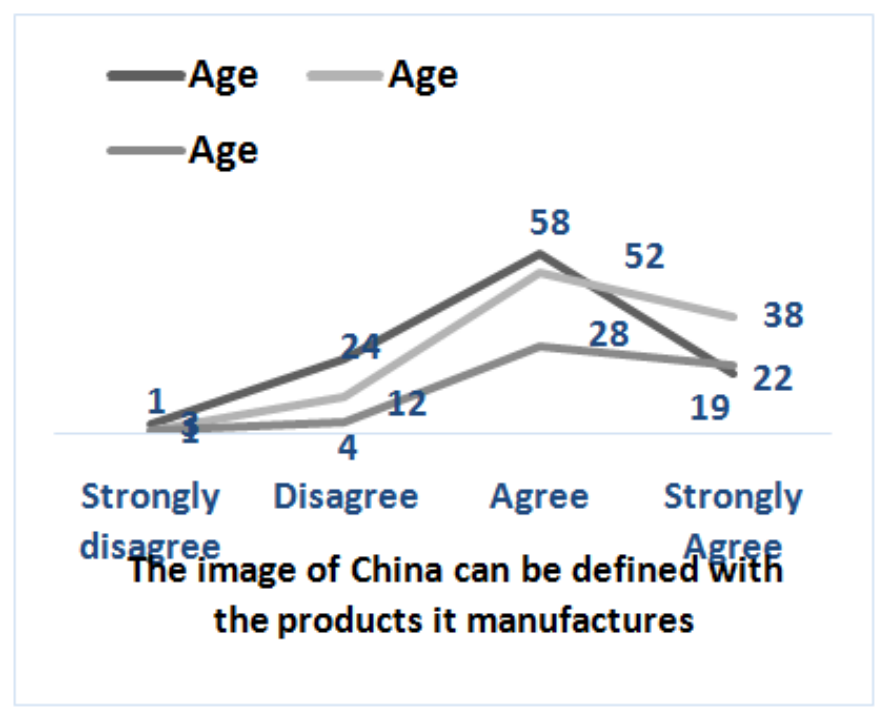

Graph 1Age and the attitude toward the statement

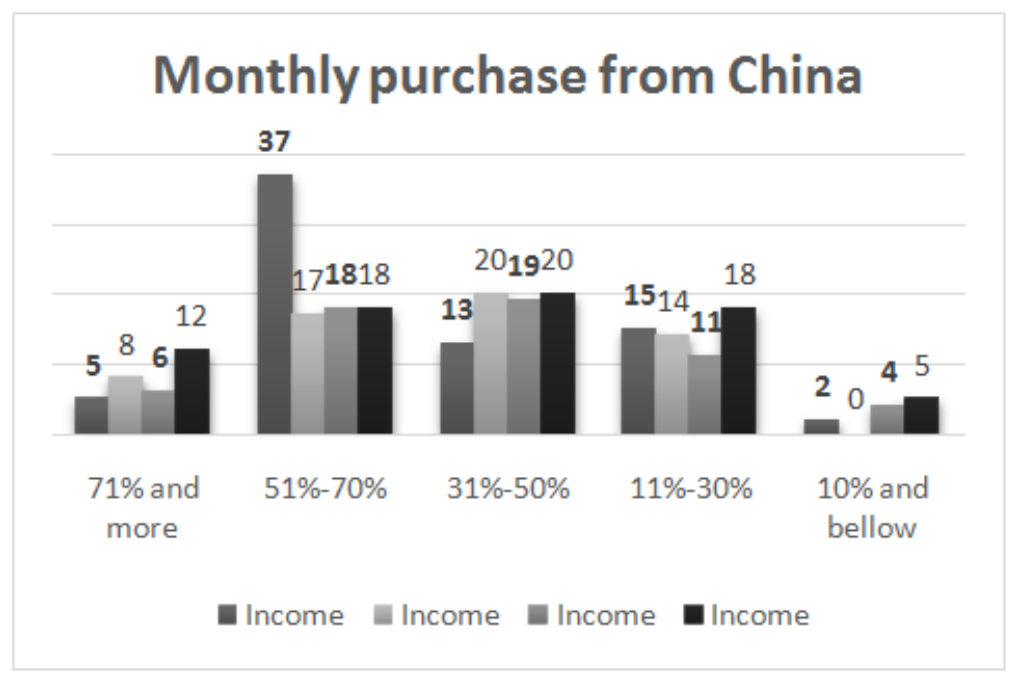

Graph 2Monthly purchase in dependence of income 


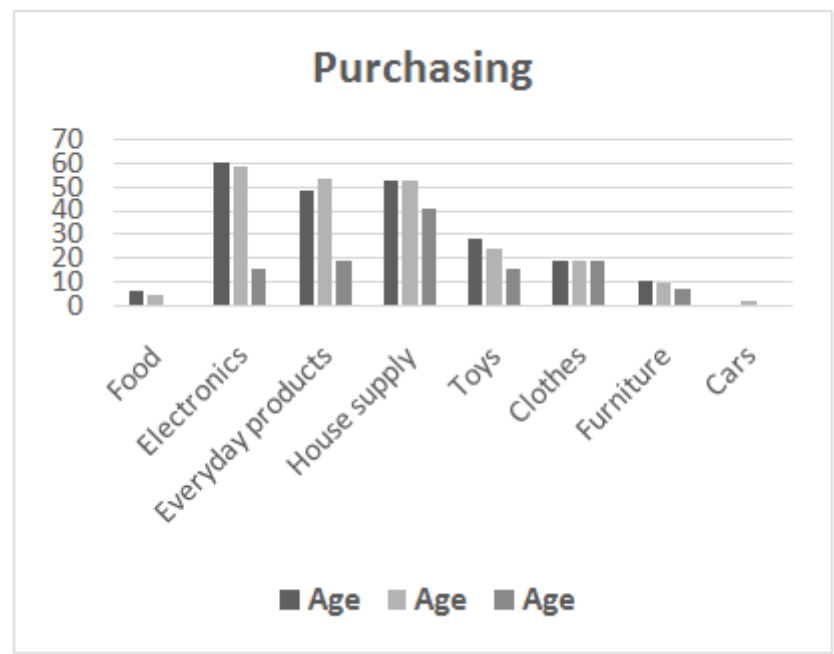

Graph 3The type of products bought in dependence of age

\section{References}

[1]. Aaker, D. (1991). Managing brand equity. New York : Free Press.

[2]. Anholt, S. (2003). Brand New Justice: the upside of global branding. Oxford: Oxford: Butterworth Heinemann.

[3]. Anholt, S. (2007). Competitive identity. The new brand management for nations, cities and regions. New York: Palgrave Macmillan

[4]. Anholt, S. (2008). Competitive identity: new brand management for nations. Gatko Forum 7(1), 11-20.

[5]. Baladi, J. e. (2012). Remaking "Made in China". JWT, 10-20.

[6]. Chinen, K., \& Sun, Y. (2011,06). Effects of country-of-origin on buying behaviour: A study of attitudes of united states consumers to chinese brand automobiles. International Journal of Manaement, Vol. 28, pg. 553-563.

[7]. Economist, p. e. (2014, 10 11). Chinas's back. Preluat pe 02 22, 2015, de pe Economist: http://www.economist.com/news/financeand-economics/21623758-chinas-back

[8]. FutureBrand. (2014-15). Country Brand Index. Preluat pe 05 15, 2015, de pe www.futurebrand.com: http://www futurebrand com/uploads/CBI-14 15-LR pdf

[9]. Gtai. (2015). 125 Years of Excellence. Preluat pe 03 26, 2015, de pe www.gtai.de: http://www.gtai.de/GTAI/Navigation/EN/Invest/Service/Publications/markets-germany,did=738904.html

[10]. Hulland, J., Todino, H. S., \& Lecraw, D. J. (1996). Country-of-origin effects on sellers' price premiums . Journal of International Marketing, 4(1), 57-79.

[11]. Josiassen, A., \& Harzing, A. W. (2008). Descending from the ivory tower: Reflections on the relevance and future of countryoforigin research. European Management Review, 5(4), 264-279.

[12]. Kahneman, D., Tversky, A., \& Slovic, P. (1981). Judgement under uncertainty: Heuristics and biases. New York: Cambridge University Press.

[13]. Keith, D. (2003). Country of origin 1965-2004: a literature review. Journal of Customer Behavior.

[14]. Kotler, P. (2000). Marketing Management (Millenium Edition ed.). Prentince Hall.

[15]. Kotler, P., \& Armstrong, G. (2004). Principles of Marketing, 10th Edition. Upper Saddle River: Pearson Prentice Hall.

[16]. Kotler, P., Armstrong, G., Wong, V., \& Saunders, J. (2008). Principles of Marketing. London: Prentice Hall.

[17]. McEwen, W. (2005). Married to the brand. New York: Gallup Press.

[18]. Moilanen, T. (2008). How to brand nations, cities and destinations. A planning book for place planning. New York: Palgrave Macmillan.

[19]. Nagashima. (1970, January). Comparison of Japanese and US attitudes toward foreign products. Journal of Marketing, vol. 34, No. $1,68-74$.

[20]. Nagashima, A. (1977). A Comparative "Made in" Product Image Survey among Japanese Businessmen. Journal of Marketing, vol 41, No 3, 95-100.

[21]. Ozretic-Dosen, D., Skare, V., \& Krupka, Z. (2007). Assessments of country of origin and brand cues in evaluating a Croatian, western and eastern European food product. Journal of Business Research, 60(2), 130-136.

[22]. Sexton, D. (2008). Branding. În D. Sexton, Trump University Branding: How to build the most Valuable Asset of Any Business (pg. 10-81). Trump University.

[23]. Shimp, T., \& Sharma, S. (1987). Consumer Ethnocentrism Construction and Validation of the CETSCALE. Journal of Marketing Research 24 (3), 280-289.

[24]. Usunier, J. (2006). Relevance in Business Research: The Case of Country of Origin Research in Marketing. European Management Review 3(1), 60-78.

[25]. Vrontis, D., Thrassou, A., \& Vignali, C. (2006). The country-of-origin effect on the purhcase intention of apparel: Oportunities and threats for small firms. International Journal of Entrepreneurship and Small Business Vol. 3, pg. 459-476.

[26]. Wagner, D. (2008). International perspectives on counterfeit trade. MIT Sloan Management Review 49(4), 9-10.

[27]. Wilky, W., \& Nes, E. (1982). Country of origin effects on product evaluation. Journal of International Business Studies 8(1), pg. 89-99.

[28]. Williams, J. (2010). The Basics of branding. Entrepreneur. 